\title{
MAPPING THE NITROGEN STATUS ON IMMATURE OIL PALM AREA IN MALAYSIAN OIL PALM PLANTATION WITH AUTOPILOT TRACTOR-MOUNTED ACTIVE LIGHT SENSOR
}

\author{
ROHAIDA MOHAMMAD*; DARIUS EL PEBRIAN*; MOHAMMAD ANAS AZMI* \\ and EZRIN MOHD HUSIN ${ }^{\star *}$
}

\begin{abstract}
This study was conducted to identify and visualise spatially the Nitrogen (N) status on immature oil palm area with an autopilot tractor-mounted active light sensor (ALS) in a Malaysian oil palm plantation. All the measurements taken by the ALS were assessed 'on-the-go' at every second while the tractor was moving on the field with autopilot steering mode. The $N$ status was analysed based on $46 \%$ of the $N$ content in urea and $40 \mathrm{~kg} \mathrm{ha-1} N$ application rate for a standard fertiliser requirement for immature oil palm. The ordinary kriging method was used to produce the interpolated maps of the N status by means of the ArcGIS 10.3 software. It was found that mean N-as applied rate per hectare read by the sensor was $1.62 \%$ lower than the recommended one. By showing such very small difference in mean rates, generally, the system showed its effectiveness in monitoring $N$ status on immature oil palm. The interpolated maps also successfully displayed spatial variability of the $N$ status on immature oil palm area, which are useable for reference in applying variable rate application (VRA) to economise the use of fertiliser on the said crop.
\end{abstract}

Keywords: autopilot tractor, active light sensor (ALS), N fertiliser.

Received: 22 June 2020; Accepted: 27 January 2021; Published online: 7 April 2021.

\section{INTRODUCTION}

Since its early introduction, agricultural mechanisation has been proving its role in helping the farmers to improve the productivity of operations in farmland. The Food and Agriculture Organization (FAO, 2014) stated that agricultural mechanisation has changed power source in agriculture from human to tractor. The change has enabled expanding the areas and capacity of operation to maximise productivity. Through its significant role since the past centuries, Bello (2012) added that agriculture mechanisation was

\footnotetext{
Faculty of Plantation and Agrotechnology,

Universiti Teknologi MARA Melaka,

77300 Jasin Campus, Merlimau, Melaka, Malaysia.

E-mail: darius@uitm.edu.my

** Smart Farming Technology Research Center,

Universiti Putra Malaysia,

43400 UPM Serdang, Selangor, Malaysia.
}

recognised as one of the greatest engineering achievements of the $20^{\text {th }}$ century.

Through the years, the agricultural mechanisation technology is being continuously enriched. The advancement of today's modern technology has allowed tractor to be equipped with the autopilot system. This automatic-auto guidance steering in driving the tractor gives various benefits to the farmers. The use of automatic-auto guidance steering can improve performance such as tillage, planting operation and soil compaction. This technology also has been claimed to be capable of reducing overlaps of tractor passes in the field, increasing the tractor speed during operation and extending workdays by giving the greatest flexibility in working hours and hiring labour. It also gives more appropriate placement inputs in crop production (Lipinski et al., 2016; Bechar and Vigneault, 2016; 2017). A study on cotton planting conducted by Bergtold et al. (2013) showed that 
the distance between the plants rows and tillage passes were accurately maintained, and the number of planted cotton seeds were also reduced by as much as $24 \%-52 \%$ and the net revenues from cotton yields were increased by as much as 38\%$83 \%$ as well. They also added that an economic analysis of on-farm adoption showed that the autoguidance systems with an accuracy of less than 2.5 $\mathrm{cm}$ may be the most profitable for larger farms, while systems with less than $10 \mathrm{~cm}$ accuracy may provide a better economic alternative for smaller farms.

The Nitrogen (N)-sensor made by Yara International (2015) is a common active light sensor (ALS) system mounted on tractor roof. The sensor was developed to determine the crop $\mathrm{N}$ status and to enable variable-rate fertilisation 'on-the-go'. The determination was made by measuring the light reflectance properties that were reflected from crop canopies. The N-sensor technology also could estimate biomass and $\mathrm{N}$ demand of a crop from different wavelength levels of the reflected light. $\mathrm{N}$ is an integral part of chlorophyll, hence, the $\mathrm{N}$ supplies must be adequate for favourable crop growth conditions. $\mathrm{N}$ is a key element for photosynthesis, respiration, and transpiration since it is included amino acid, proteins, and nucleic acid. The losses of $\mathrm{N}$ due to leaching, surface run-off, denitrification, volatilisation and ammonium fixation by clay minerals will strongly affect the crop nutrient uptake. Thus, it may also delay crop production for up to 36 months (Goh and Harter 2003). While, Amirruddin and Diyana (2017) mentioned that chlorophyll contents of crop leaves were strongly affected by $\mathrm{N}$ status. Therefore, reviewing the abovementioned literatures, it is highly recommended to apply fertiliser at the right rate because it is not only able to reduce the production costs, but also to sustain maximum yield.

Laboratory analysis methods such as Kjeldahl digestion and Dumas combustion (Muñoz-Huerta et al., 2013) had been commonly used for $\mathrm{N}$ analyses. However, these analyses are destructive to the sample and need sample pre-processing. Besides that, such analyses can cause $\mathrm{N}$ loss because of deficient burning. Today's modern technology, which has embedded the farm tractor with remote sensing (RS), has created the opportunities to implement 'on-the-go' ALS technology for assessing foliar nutrients. This technology can overcome the limitation of the said previous methods. By adopting this technology, according to Mulla (2013), the Yara-N sensor installed on the roof of tractor has successfully determined the $\mathrm{N}$ status on crop based on the normalised difference vegetative index (NDVI). In fact, Samborski et al. (2009) mentioned that the use of such sensor also has overcome the limitation of the chlorophyll meter in directly estimating the crop $\mathrm{N}$ status.
The tractor-mounted N-sensor has been widely used to determine the real-time $\mathrm{N}$ status on crops since it was introduced in Germany as its country of origin, in the last two decades. Singh et al. (2015) used tractor-mounted N-sensor to develop an algorithm for $\mathrm{N}$ application on locally recommended wheat crop in India. Molin and Port (2010) mapped the variability of $\mathrm{N}$ uptake and biomass production on sugarcane planted in Brazil by using tractormounted N-sensor. Also, in Brazil, Bragagnolo et al. (2013) evaluated the efficiency of an optical crop sensor to assess the nutritional status of corn. Tremblay et al. (2008) investigated the performances of two commercial N-sensors to assess the status of $\mathrm{N}$ in spring wheat and maize cultivation in Canada. Elsayed et al. (2015) compared the performance of active and passive reflectance sensors that were mounted on a frame in front of a tractor to assess the normalised relative canopy temperature and grain yield of drought-stressed barley cultivars in Southwestern Germany.

The above-mentioned past studies mostly focused on the use of this technology on cereal crops and annual crops. This is in line with the main intended use of the sensor by the manufacturer from its country of origin, which focused on winter wheat, oilseed rape, maize and barley during early growth stages (Yara International, 2015). This might be also because most of the canopy height of annual crops or cereal crops are shorter than the sensor height that is mounted on the tractor roof. As reported by Sharma et al. (2012) and Singh et al. (2015), the tractormounted ALS N-sensor height ranged from 1.60$2.74 \mathrm{~m}$ from the ground. Majority of annual crops or cereal crops height are below the range. Thus, assessment of $\mathrm{N}$-status on annual crops and cereal crops in the fields are more easily performed rather than on perennial tree crops, which are usually as tall plants. In Malaysia, Husin (2017) reported that the use of this technology has been initiated to monitor $\mathrm{N}$ status in paddy field through a research platform. It was successfully operated by means of a tractor driven by manual steering.

Despite this technology has been claimed to have potential for use on cereal crops and annual crops, nonetheless, as far as we know no one has studied its use on perennial tree crop such as oil palm. Thus, evaluation of this technology for use on oil palm has become a prime interest. It is a fact that oil palm characteristics and its cropping system is very much different from that of the winter wheat, oilseed rape, maize and barley, which the sensor has been applied on. Thus, its new potential for use on oil palm can be explored in an effort to enhance the field operations in Malaysian plantations to be always integrated with the updated technology. As one of the industrial crops that has been planted on more than 5.7 million hectares land in Malaysia in 2016 (Kushairi et al., 2017), oil palm always 
needs a constant driving of the latest technology in order to remain sustainable and competitive. This is also in line with Malaysia's aspiration to become a self-sufficient industrialised nation with a strong agricultural-based industry. Apart from that, elements of technology are important to reduce the strenuous tasks, minimise the harsh field environment, and create a better working condition in oil palm plantation as stated by Pebrian et al. (2014). Therefore, all changes and technological innovations that are relevant to oil palm should be applied to this plantation industry, particularly to suit this industry with the Industrial Revolution (IR) 4.0 era.

Thus, the study aimed to identify and visualise spatially the $\mathrm{N}$ status on immature oil palm area using an autopilot tractor-mounted N-ALS sensor. This study is possible to be carried out because during the early growth stages (immature palms), the palm height is reachable by the sensor that is mounted on the tractor roof. The outcomes of this study would be able to contribute towards strengthening the integration of technology elements in fertiliser application, especially in VRA to economise the use of fertiliser on oil palm. Besides that, it also promotes the utilisation of precision agriculture technology through the use of autopilot tractor and real-time sensor to the oil palm industry.

\section{MATERIALS AND METHOD}

\section{Experimental Area and Equipment}

The data was comprehensively collected through a field experiment in an oil palm plantation at Kempas estate, Jasin, Melaka, Malaysia. The estate is operated under the management of Sime Darby Plantation Berhad. The sensed object was the immature oil palm (Elaies guineensis) planted on 4.5 ha land of Bungor soil series. The experimental area is on the coordinates of $\mathrm{N} \mathrm{02}{ }^{0} 15.414^{\prime \prime}$ and $\mathrm{E}$

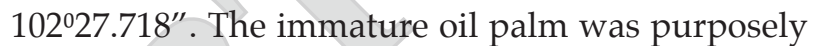
chosen as the sensed object because of such comprehensive field experiment has never been conducted directly in any oil palm plantation in Malaysia. Another reason was that the immature oil palm height was accessible by $2.74 \mathrm{~m}$ maximum height of the tractor-mounted ALS N-sensor as previously reported. The sensor, however, is not appropriate for assessing $\mathrm{N}$ status on the mature palms with height varying from $10-20 \mathrm{~m}$. Aside from that, early identification of $\mathrm{N}$ status during immature stage in oil palm growth is the best approach for fertilisation management practice.

In the study area, the palms were comprised of dura x pisifera (DxP) variety at 24 months old and planted in the field in a triangular spacing at $9 \mathrm{~m} \times 9 \mathrm{~m} \times 9 \mathrm{~m}$ in accordance with common standard of planting arrangement. Soil texture on most of the experimental plots were identified as clayey texture. Such texture is categorised under low organic matter content. This was in agreement with Gasim et al. (2011), who stated that clayey texture was characterised by low organic matter. Hence, the soils had also low $\mathrm{pH}$ and low electrical conductivity (EC). The slope ranging from flat to undulating with an average slope of $9^{\circ}$. The study was carried out in the dry season in November 2019 under an average of $32^{\circ} \mathrm{C}$ daily ambient temperature. The weather was hot and cloudy with haze as forest fires occurring in a neighbouring country due to regional and seasonal severe weather phenomena at the time.

A TD5.75 New Holland tractor at 75 horsepower engine size that was equipped with an autopilot system consisting of Trimble ${ }^{\circledR}$ EZ-Pilot ${ }^{\circledR}$ Steering System and Trimble ${ }^{\circledR} \mathrm{Fm}^{\circledR}{ }^{\circledR} 2050$ Plus Application were used as the main components of the system. The Yara N-sensor was integrated into the system to examine the $\mathrm{N}$ status. The specifications of the tractor and the autopilot-automated steering system are shown in Tables 1 and 2. Whilst, the description of Yara N-sensor is presented in Table 3.

\section{Experimental Procedure}

The field experiment was carried out on $300 \mathrm{~m}$ x $150 \mathrm{~m}$ plot size. The plot was divided into three sub-plots to repeat the field experiment for three replications (Figure 1). Each replication had eight tractor passes; hence, the whole experimental plots had 24 tractor passes. At the start of the experiment, the palm trees were just transplanted to the field from the nursery. Being newly transplanted, the palms in the field have not received any fertiliser. Therefore, the $\mathrm{N}$ content on the crops originally came from the nursery treatment and the natural sources.

The Yara ALS was attached on the roof of the tractor and operated to determine $\mathrm{N}$ status on the crop in the study area (Figure 2). The determination of $\mathrm{N}$ status on immature palms started at the first pass and ended at the $24^{\text {th }}$ pass. Throughout the operation, the tractor was driven with autopilot steering mode, and the engine speed was set at $2000 \mathrm{rpm}$. Before commencing the field experiment, an agronomic calibration was done manually on the onboard sensor display. In this calibration, the values of $40 \mathrm{~kg} \mathrm{ha}^{-1} \mathrm{~N}$ for a standard application rate on immature oil palm and $46 \% \mathrm{~N}$ content in urea fertiliser as recommended by $\mathrm{Ng}$ (1979) were entered into data processing unit of the onboard computer. These values were assigned to be reference rate for the sensor since the reference rate for $\mathrm{N}$ application on oil palm is not listed in the sensor library. Actually, the sensor has been calibrated by its manufacturer, but for the $\mathrm{N}$ 
application rates on selective crops only (i.e. wheat, oilseed rape, barley, maize). Therefore, only these crops are available in the sensor library. Whereas, calibration for $\mathrm{N}$ application rates on other crops, which are not listed in the sensor library has be to carried out manually. By putting the values of $40 \mathrm{~kg}$ $\mathrm{ha}^{-1} \mathrm{~N}$ application rate for immature oil palm and $46 \% \mathrm{~N}$-content in urea fertiliser into the computer, the ranges of application rates can be set as the maximum (69-75 $\left.\mathrm{kg} \mathrm{ha}^{-1}\right)$ and minimum (9.3-10.1 kg $\mathrm{ha}^{-1}$ ). During mapping of the $\mathrm{N}$ status, the terrain elevations were also measured simultaneously by using the Global Navigation Satellite System (GNSS) embedded to the tractor. Figure 3 shows the schematic of sensing operation in the field by the $\mathrm{N}$-sensor.

TABLE 1. SPECIFICATION OF TRACTOR

\begin{tabular}{|c|c|c|}
\hline Section of tractor & Component & Numbers or specification \\
\hline Engine & $\begin{array}{l}\text { Number of cylinder / aspiration/valves } \\
\text { Emission level } \\
\text { Capacity } \\
\text { Rated horsepower-ISO TR } 14396 \text { - ECER120 } \\
\text { Rated engine speed } \\
\text { Maximum torque - ISO TR14396 } \\
\text { Fuel tank capacity } \\
\text { Service intervals }\end{array}$ & $\begin{array}{l}4 / \mathrm{T} 1 / 2 \\
\text { Tier } 3 \\
3908 \mathrm{~cm}^{3} \\
56 / 75 \\
2300 \mathrm{rpm} \\
298 @ 1400 \\
110 \text { litres } \\
300 \mathrm{hr}\end{array}$ \\
\hline Hydraulic & $\begin{array}{l}\text { Main pump flow } \\
\text { Mega flow pump flow } \\
\text { Steering and services pump flow } \\
\text { (mechanical/hydraulic shuttle) }\end{array}$ & $\begin{array}{l}36 \text { litres } \min ^{-1} \\
48 \text { litres } \min ^{-1} \\
29 \text { litres } \min ^{-1}\end{array}$ \\
\hline Remote valves & $\begin{array}{l}\text { Type } \\
\text { Maximum number rear valve } \\
\text { Maximum number midpoint mount valves }\end{array}$ & $\begin{array}{l}\text { Deluxe } \\
3 \\
2\end{array}$ \\
\hline Linkage & $\begin{array}{l}\text { Maximum lift capacity of ball end } \\
\text { Maximum lift capacity through the range } \\
\text { ( } 610 \mathrm{~mm} \text { behind ball ends) }\end{array}$ & $\begin{array}{l}3565 \mathrm{~kg} \\
2700 \mathrm{~kg}\end{array}$ \\
\hline
\end{tabular}

TABLE 2. SPECIFICATIONS OF AUTOPILOT MECHANISM

\begin{tabular}{|c|c|c|}
\hline An aspect of the autopilot mechanism & Component & Specification \\
\hline Brand & Trimble & Steering system and plus integration \\
\hline Steering & $\begin{array}{l}\text { Steering motor } \\
\text { Connector }\end{array}$ & $\begin{array}{l}\text { SAM - } 200 \text { steering motor } \\
\text { IMD - } 600 \text { to SAM } 200 \text { CAN } \\
\text { Power cable }\end{array}$ \\
\hline System & $\begin{array}{l}\text { DC power } \\
\text { Processor } \\
\text { Storage }\end{array}$ & $\begin{array}{l}\text { Supplied by TW-200, } 27 \text { volts, } 35 \text { amps } \\
1 \text { GHz quad core } \\
\text { Primary embedded memory - } 32 \text { GB }\end{array}$ \\
\hline Mec & $\begin{array}{l}\text { Dimension } \\
\text { Weight } \\
\text { Mount }\end{array}$ & $\begin{array}{l}312 \times 214 \times 45 \mathrm{~mm} \text { (plus connector) } \\
2.5 \mathrm{~kg} \\
4 \mathrm{MP} \text { screws on } 75 \mathrm{~mm} \text { centres }\end{array}$ \\
\hline & $\begin{array}{l}\text { Material } \\
\text { Environmental rating }\end{array}$ & $\begin{array}{l}\text { Magnesium } \\
\text { IP55 }\end{array}$ \\
\hline $\mathrm{C}$ & $\begin{array}{l}\text { USB ( } 1 \text { sider facing, } 1 \text { rear facing) } \\
\text { Ethernet (vis TM-200) } \\
\text { CAN (source 5VDC) } \\
\text { Port Expender (optional) } \\
\text { HDMI output }\end{array}$ & $\begin{array}{l}\text { USB } 2.0 \\
\text { RJ45 connector } \\
\text { RJ11 connector } \\
1 \text { port for CAN Bus, I/O and serial } \\
\text { DVI connector }\end{array}$ \\
\hline Temperature & $\begin{array}{l}\text { Operation } \\
\text { Storage }\end{array}$ & $\begin{array}{l}0^{\circ} \mathrm{C}-65^{\circ} \mathrm{C} \\
-40^{\circ} \mathrm{C}-85^{\circ} \mathrm{C}\end{array}$ \\
\hline LCD Display & $\begin{array}{l}\text { Size } \\
\text { Touchscreen } \\
\text { Resolution } \\
\text { Brightness (adjustable) }\end{array}$ & $\begin{array}{l}307 \mathrm{~mm} \\
\text { Protection capacitive touch } \\
1280 \times 800 \\
1000 \text { candela m} \mathrm{m}^{-3}\end{array}$ \\
\hline Front facing camera & $\begin{array}{l}\text { Type } \\
\text { Resolution }\end{array}$ & $\begin{array}{l}\text { Low light level, colour } \\
1.3 \text { megapixel }\end{array}$ \\
\hline
\end{tabular}

Note: CAN - controller area network; CAN Bus - controller area network bus; I/O - input/output; DVI - digital visual interface.

Source: Trimble (2014a; 2014b). 
TABLE 3. DESCRIPTION OF N-ACTIVE LIGHT SENSOR

\begin{tabular}{ll}
\hline Yara active light sensor aspect & \multicolumn{1}{c}{ Description } \\
\hline N-sensor and mounting & $\begin{array}{l}\text { N-sensor was mounted on the top of a multi-utility vehicle, has a conditioner cabin, providing } \\
\text { the adequate working temperature to the operator }\end{array}$ \\
Consist & $\begin{array}{l}\text { Fibre optics and a microprocessor in a hard shell, placed on the roof tractor, two diode } \\
\text { spectrometers - one spectrometer analysed crop reflectance received by four lenses with an } \\
\text { oblique view on to the crop spectrometer and the second spectrometer was used to measure } \\
\text { irradiance of ambient light for permanent correction of the reflectance signal to ensure stable } \\
\text { measurement (two on each side of the vehicle) }\end{array}$ \\
Scanned & $\begin{array}{l}\text { Both sides of the vehicle during its movement in the crop, the measurements were taken on the } \\
\text { crop from four different angles }\end{array}$ \\
Connected & $\begin{array}{l}\text { Global positioning system (GPS) - Signal to allow location, sensor and application information } \\
\text { to be plotted enabling the production of biomass and Nitrogen application map for field }\end{array}$ \\
Spectrometer collects reflectivity & $\begin{array}{l}\text { Its spectrometers analysed crop light reflectance received and another one was used in estimated } \\
\text { the irradiance conditions. The whole process of determining the crop's Nitrogen requirement } \\
\text { and apply at the correct fertiliser rate happened instantaneously with no time delay }\end{array}$
\end{tabular}

Source: Sharma et al. (2012) and Singh et al. (2015).

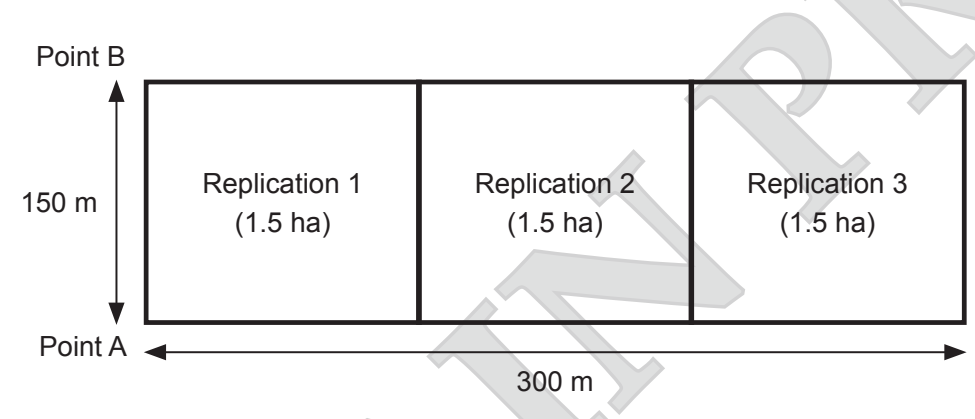

Figure 1. Field experimental layout of operation of autopilot tractor-mounted $N$-sensor.

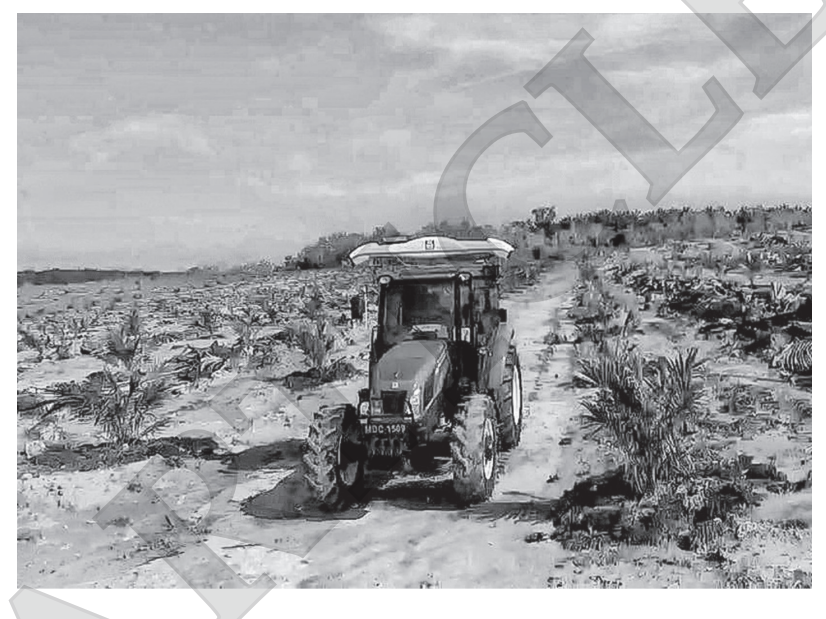

Figure 2. Autopilot tractor-mounted N-sensor is assessing $N$ status on the immature palms in the study area.

\section{Data Processing}

The data obtained from the sensor were transferred online to the Sensor Office website (www.sensoroffice.com) for generating spatial variability maps sensor. In the Sensor Office, the biomass index and $\mathrm{N}$-application were processed to generate the intended parameters, which

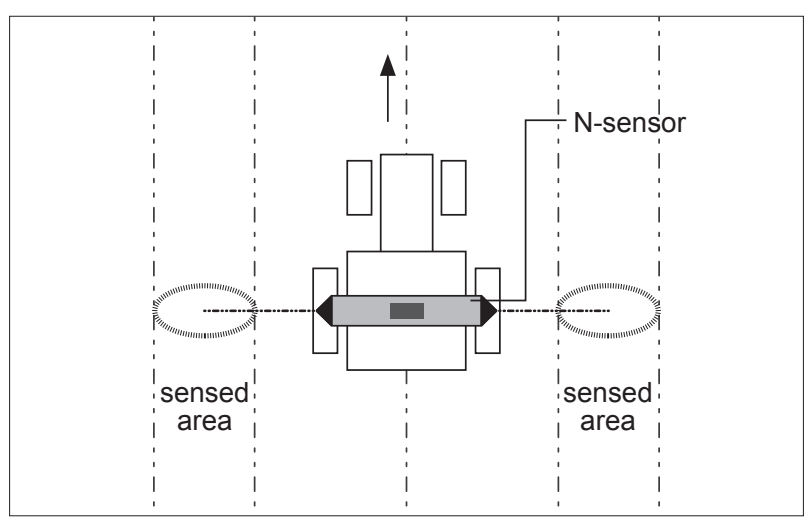

Source: Yara (2015).

Figure 3. The schematic of sensing operation in the field by the $N$-sensor.

consisted of $\mathrm{N}$ recommended, $\mathrm{N}$ as-applied and biomass index. Data processing in the Sensor Office website began with the extraction of collected data by its software. The collected data points were converted into raster maps of selected parameters ( $\mathrm{N}$ recommended, $\mathrm{N}$ as-applied, biomass). The $\mathrm{N}$ recommended map indicates the rate of $\mathrm{N}$ that has been recommended for the crop in an area. Usually 
the plantation managers have already known the recommended rate for fertiliser application on his crop. While, the $\mathrm{N}$ as-applied map shows the actual rate of $\mathrm{N}$ as- applied or $\mathrm{N}$ as-placed on the crop either by means of manual or mechanical systems. Normally, the result of fertilising operation is expressed as the rate as-applied. The biomass map shows the matter derived from oil palm. Biomass can indicate the availability of $\mathrm{N}$, thus, the more the biomass, the high is the availability of $\mathrm{N}$, or vice versa.

The CardWriter in the software was used to convert (.log) file format to (.csv)/ excel file format. Having these files, the raw data can be viewed in excel format. The fertiliser and biomass were expressed in kg per hectare. Sensor Office software actually also provided raster maps to be used for spatially variable information or prescription maps. These prescription maps can be used optionally to control the application rate. The sequent command menu for creating raster maps in Sensor Office software are as follows: (1) Sensor Office, (2) Services, choose file (.log file), (3) Start Demo, (4) Tick/ untick Parameters, (5) Point data preview creates a raster map with square raster cells, (6) Next and (7) Report.

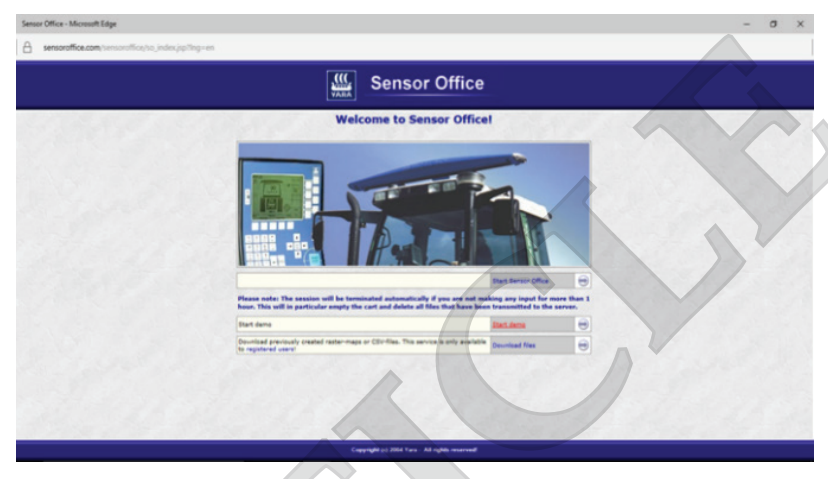

Step 1. From the web: www.sensoroffice.com choose "Start Demo".

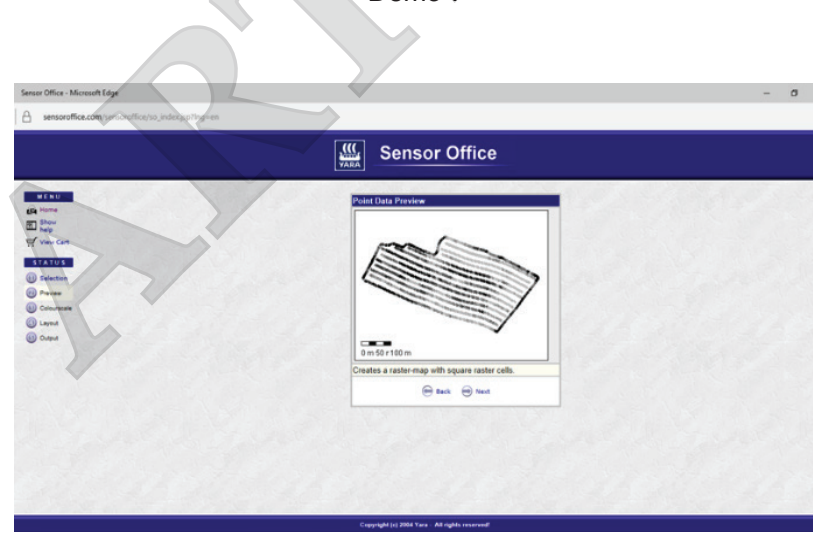

Step 3. Point data preview. The raster map with square raster cells, then clicking the "Next" button.
Figure 4 shows the sequences of data processing in the Sensor Office software.

All the data of $\mathrm{N}$ recommended, $\mathrm{N}$ as-applied, biomass index and elevation were used for further analysis and visualisation of $\mathrm{N}$ status. The ArcGIS 10.3 software was then used to generate raster maps by converting (.log) file format to (.csv) file. The identified spatial variability maps were generated by using the interpolation method with a spherical model in an ordinary kriging method. The Kriging Model classes define the kriging method and its parameters that will be used in a kriging interpolation. Ordinary kriging is most commonly used among the kriging methods and is the default. It assumes that the constant mean is unknown because the advanced parameters for lag size and the variogram parameters for major range, partial sill and nugget are not determined. The default parameter values are determined by the wizard in the software, unless there is a scientific reason to reject the mean.

In the data processing, the data input (.xls and .csv files) from the Global Positioning System (GPS) receiver on the New Holland TD 5.75 tractor was run in Toolbox of ArcMap interface. Its data

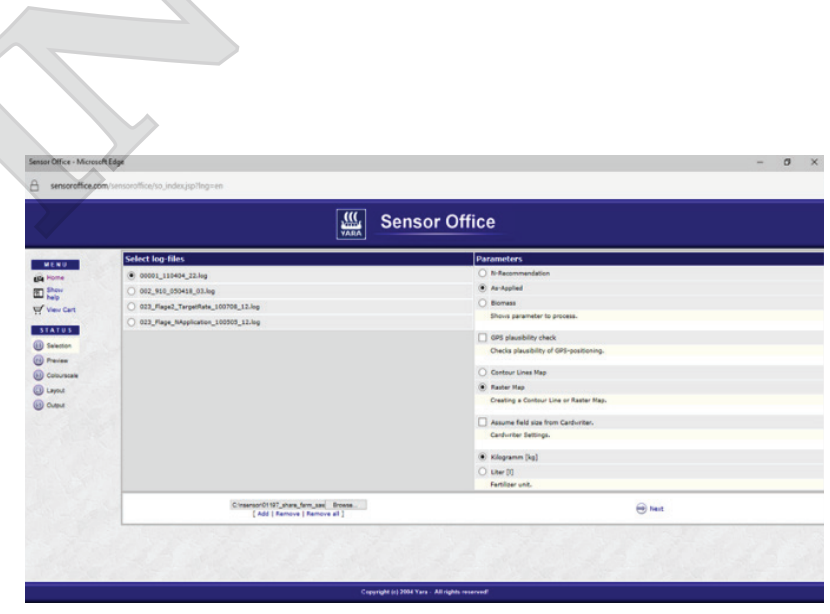

Step 2. Select log-files. Tick/untick at the parameters before proceeding "Next".

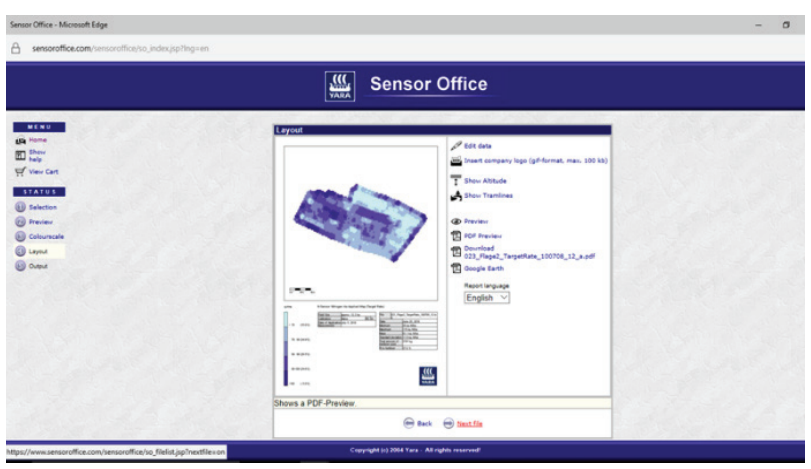

Step 4. Clicking "Report". The layout can be edited before saving as PDF format. 
consisted of latitude and longitude (X-axis and Y-axis) coordinates. The raster maps with World Geographical System (WGS) 1984 coordinates were transformed into Kertau Zone $48 \mathrm{~N}$ of Universal Transverse Mercator (UTM) in XY-plane of Cartesian coordinates for converting into the specific current coordinates system in Malaysia. In simple steps, development of spatial variability maps with ordinary kriging method was made by clicking the sequent menu as follows: (1) Projected Coordinate System, (2) UTM, (3) Kertau UTM Zone $48 \mathrm{~N}$, (4) Data Display in meter unit, (5) ArcCatalog, (6) Shapefile, (7) Start Editing, (8) Add New Field to the table attributes, (9) Calculate Geometry. For the ArcToolbox, (10) Spatial Analysist Tools, (11) Interpolation, (12) Kriging, (13) Properties at Symbology, (14) Map display in label view, (15) Layout view to edit, (16) Insert legend items, (17) Complete map can be saved in .jpeg format by export map.

Through the parameters selected, the N-sensor produced three types of raster maps namely $\mathrm{N}$ recommendation map, $\mathrm{N}$ as-applied map and biomass map. Then, the interpolated maps of $\mathrm{N}$-and biomass status can be grouped in table classes by means of classification command in ArcGIS software. The classification in ArcGIS 10.3 was generated by clicking the sequent menu: (1) Layer properties, (2) Symbology (3) Classification (4) Method (5) Classes (6) Break value. Generally, the table was classed as very low, low, moderate, high and very high ranges. Lastly, the raster maps can be printed out or saved as a PDF file. This file is required to support the vector and raster graphics in a single compacted file. On top of that, PDF file provides a document that can be printed or viewed on-screen. Also, PDF file allows the users to interact with the map content and monitor the field work by using smartphone or tablet.

Elevation was automatically collected by the instrument that was embedded on the tractor with autopilot-automated steering system. Therefore, while moving in the field for assessing the $\mathrm{N}$, at the same time the tractor also recorded data points of elevations by using the optical sensor embedded on the navigation system of autopilot tractor and connected to a GNSS. This recorded georeferenced data was then imported to Geographic Information System (GIS). The ArcGIS 10.3 software was used to track the saved data during the operation. In ArcGIS 10.3 software, the elevation data was expressed in meter unit, and its map can be presented either in the 2D or 3D maps with contour lines made according to the class value of elevation as displayed in the interpolated map. In the study area, the elevations ranged from 20-36 $\mathrm{m}$ with $3 \mathrm{~m}$ contour interval on the interpolated map. Figure 5 shows flowchart of method used in data collection and analysis in the study.

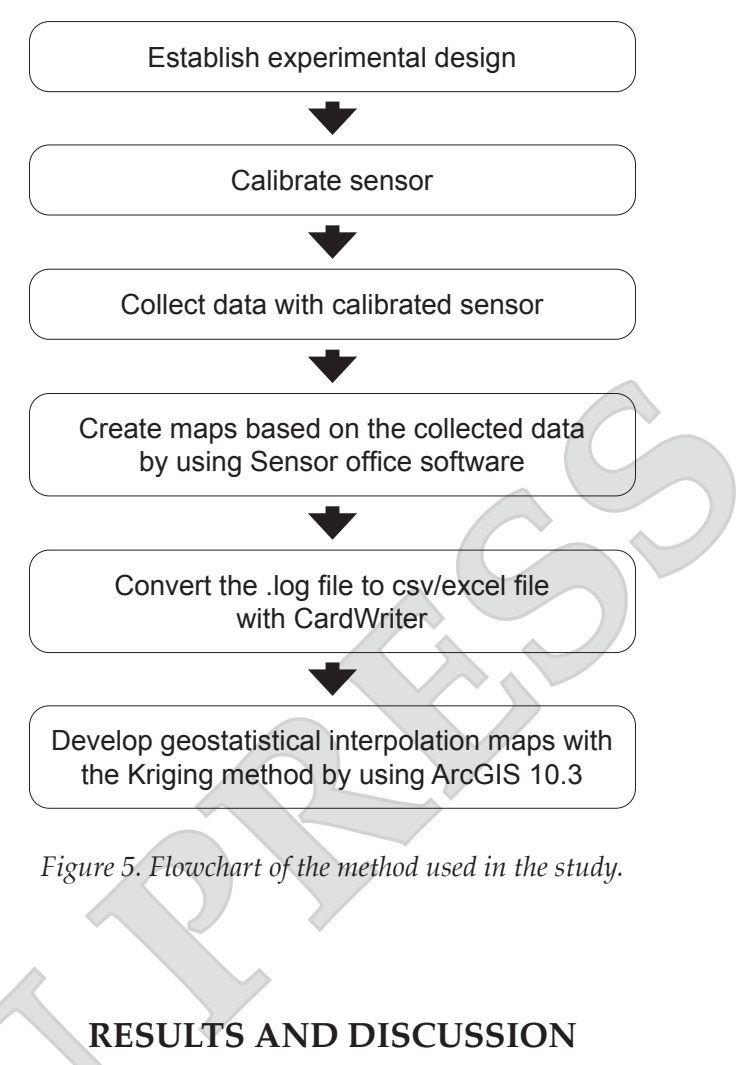

Spatial Variability of N Status and Biomass Index

The tractor-mounted N-sensor (Yara ALS) had successfully mapped the $\mathrm{N}$ and biomass status on the immature oil palms area. The spatial variability of $\mathrm{N}$ status on the maps were classed by using the raster data set colour maps function in the ArcGIS 10.3 software. Three types of maps along with their class ranges were developed by using the classification command in ArcGIS. As previously described, the $\mathrm{N}$ and biomass index status were mapped into $\mathrm{N}$ recommended map, $\mathrm{N}$ as-applied map and biomass map.

Determination of $\mathrm{N}$ rate for oil palm under the planting density of 136-148 trees per hectare can be grouped into minimum and maximum rates. The minimum rate ranged between 9.3-10.1 kg $\mathrm{ha}^{-1}$ of $\mathrm{N}$ and given at first year of field planting. The maximum rate, at $69-75 \mathrm{~kg} \mathrm{ha}^{-1}$ and $77-87 \mathrm{~kg}$ $\mathrm{ha}^{-1}$ were given at the second year and third year, respectively. $\mathrm{Ng}$ (1977) mentioned that the reference $\mathrm{N}$ rate for oil palm in age (0-3 years) is $40 \mathrm{~kg} \mathrm{ha}^{-1}$. In this study, the immature oil palms were at the second years of growth stages (Table 4 ).

TABLE 4. ESTIMATION OF NITROGEN UPTAKE AND BIOMASS INDEX FOR OIL PALM IN MALAYSIA

\begin{tabular}{lcc}
\hline Year of planting & $\begin{array}{c}\text { Nitrogen } \\
\left(\mathbf{k g ~ p a l m}^{-\mathbf{1}} \mathbf{)}\right.\end{array}$ & $\begin{array}{c}\text { Biomass } \\
\mathbf{( k g ~ p a l m}^{-\mathbf{1}} \mathbf{)}\end{array}$ \\
\hline First & 0.068 & 6.85 \\
Second & 0.509 & 57.3 \\
Third & 0.586 & 70.4 \\
\hline
\end{tabular}

Source: Ng (1979). 
The summary outputs of sensor maps in $\mathrm{N}$ recommended map and $\mathrm{N}$ as-applied map are presented in Figures 6 and 7, respectively. Generally, the $\mathrm{N}$ status in this study area was sufficient based on the reference rate. The map showed that the areas receiving the minimum application rates $(40$ $\mathrm{kg} \mathrm{ha}^{-1}$ and below) of $\mathrm{N}$ was only 1.80 ha or $39.9 \%$ of total assigned areas, while the rest obtained the maximum rates. Therefore, the area receiving minimum application rates need more $\mathrm{N}$ fertiliser supply because the content of $\mathrm{N}$ was below the recommended values.

The nutrient uptake for immature oil palms especially during the first three years after planting in the field is very important to be recorded. This is because the nutrient requirements for oil palm growth vary at different ages. Ng (1979) stressed that the estimation of annual biomass production and $\mathrm{N}$ uptake by the oil palm in Malaysia can be recommended per palm basis in $\mathrm{kg}_{\text {palm}}^{-1}$. His study concluded that the immature oil palms needs the fertiliser ranging from $10-90 \mathrm{~kg} \mathrm{~N} \mathrm{ha}^{-1}$. He also added that urea fertiliser with $46 \%$ of $\mathrm{N}$ content is normally used for fertilising oil palm.

The output also showed that the mean $\mathrm{N}$ recommended rate per hectare was $43.1 \mathrm{~kg} \mathrm{ha}^{-1}$, and the mean total $\mathrm{N}$ recommended rate for the whole areas was $193.9 \mathrm{~kg}$ (Table 5). While, the mean $\mathrm{N}$ as-applied rate per hectare was $42.4 \mathrm{~kg}$ $\mathrm{ha}^{-1}$ and the total applied rate was $190.8 \mathrm{~kg}$ (Table 6 ). The difference between the mean recommended rate and the mean as-applied rate per hectare was very small. The mean as-applied rate was found to be $0.7 \mathrm{~kg} \mathrm{ha}^{-1}(1.62 \%)$ lower than the mean recommended one. The same phenomena also happened with the mean total as-applied rate for the whole area. The total as-applied rate for the whole area was $3.1 \mathrm{~kg}(1.60 \%)$ lower than the recommended one. Generally, the differences between $\mathrm{N}$-recommended and $\mathrm{N}$-as applied rates were very small and considered as not significant. These results proved that the $\mathrm{N}$-sensor was able to work effectively in identifying and visualising the $\mathrm{N}$ status on the immature palms at the study area. $\mathrm{N}$ fertiliser stimulates vegetative growth for well-developed fruits formation, flowering and assimilation of the crop (Gianquinto et al., 2013). Consequently, the lack of $\mathrm{N}$ fertiliser can cause a decrease in plant productivity and yields (Jifon and Whaley, 2005) and the crops will become chlorotic as shown by yellowing leaves colour and stunted appearance.

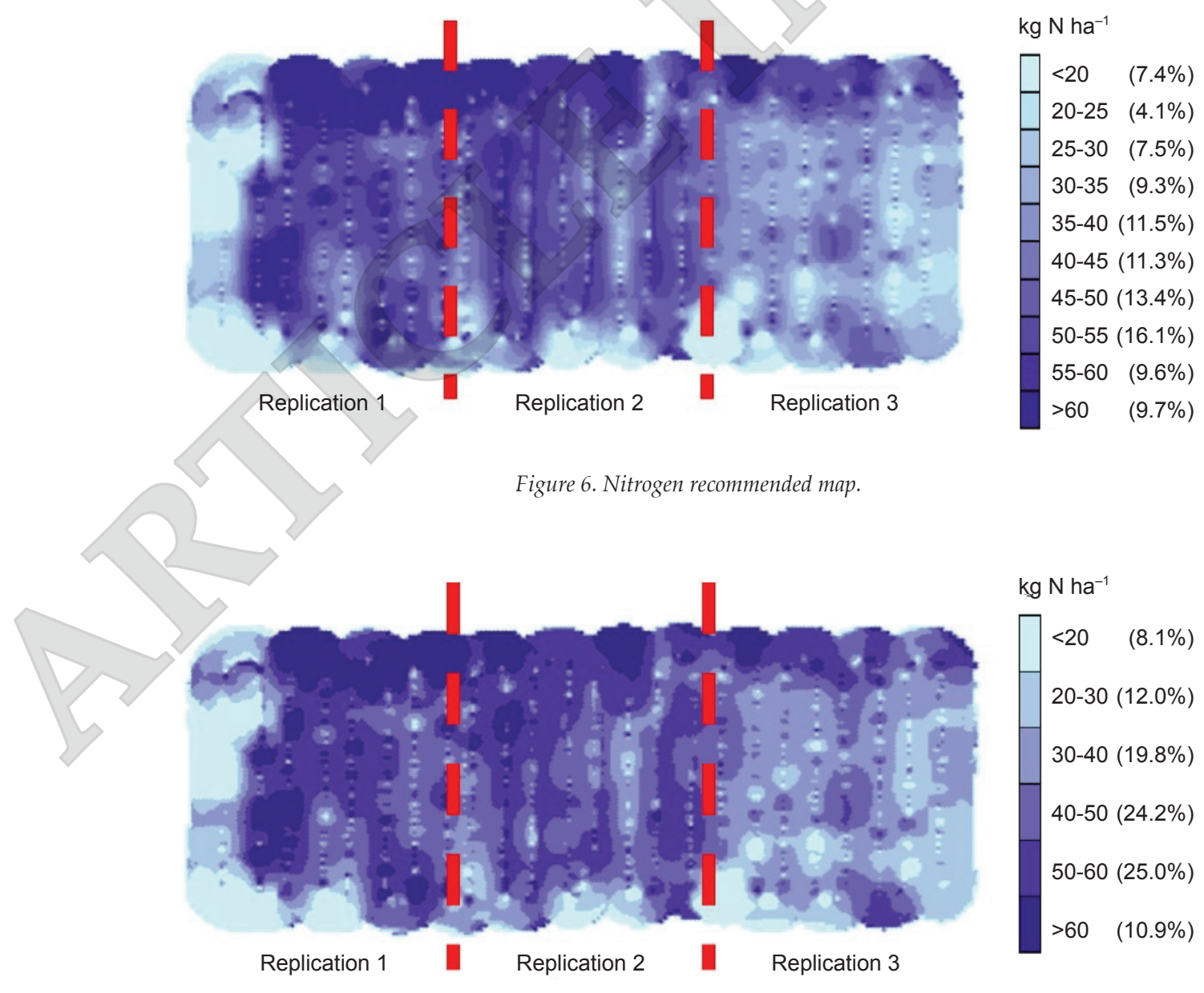

Figure 7. Nitrogen as-applied map. 
TABLE 5. SUMMARY OF NITROGEN RECOMMENDED MAP

\begin{tabular}{lc}
\hline Date of application & 18 November $\mathbf{2 0 1 9}$ \\
\hline Area & $4.5 \mathrm{ha}$ \\
Growth stage & Immature oil palm \\
Mean application rate & $43.1 \mathrm{~kg} \mathrm{ha}^{-1}$ \\
\hline Total application rate & $193.9 \mathrm{~kg}$ \\
\hline
\end{tabular}

TABLE 6. SUMMARY OF NITROGEN AS-APPLIED MAP

\begin{tabular}{lc}
\hline Date of application & 18 November 2019 \\
\hline Area & 4.5 ha \\
Growth stage & Immature oil palm \\
Mean application rate & $42.4 \mathrm{~kg} \mathrm{ha}^{-1}$ \\
\hline Total application rate & $190.8 \mathrm{~kg}$ \\
\hline
\end{tabular}

This sensor also identified the mean biomass index (Figure 8). The recorded mean biomass was $10.6 \mathrm{~kg} \mathrm{ha}^{-1}$, while the total for whole area was 48.1 $\mathrm{kg}$ (Table 7). The portion of areas with minimum and maximum biomass were $8.3 \%$ and $6.4 \%$, respectively. The recorded biomass in the study area was confirmed to be considerably lower when compared to the average ground biomass in the more mature palms with a mean of $65.9 \pm 8.7 \mathrm{mg}$ $\mathrm{ha}^{-1} 11$ years after planting and $56.04 \pm 12.0 \mathrm{mg} \mathrm{ha}^{-1}$ after 12 years after planting as studied by Lewis et al. (2020) in deep peat soil oil palm plantation in Sarawak, Malaysia. The differences in size and height of the immature and the mature oil palms have caused their average amount of ground biomass to be also different. Lewis et al. (2020) reported, the palm trunk makes the largest contribution $(33 \%-46 \%)$ to the total palm dry weight particularly in the young mature palms $(8$ years after planting) and mature palms (12 years after planting), followed by frond base which contributes $13 \%-32 \%$ of the overall biomass. This is agreeing with Poorter et al. (2015), who stated that biomass relates to the total size of the plant. This statement is also supported by Yang et al. (2017). They mentioned that there is a good relationship between plant height and biomass by showing biomass increases as plant height increases.

\section{TABLE 7. SUMMARY OF BIOMASS INDEX}

\begin{tabular}{lc}
\hline Date of application & $\mathbf{1 8}$ November $\mathbf{2 0 1 9}$ \\
\hline Area & $4.5 \mathrm{ha}$ \\
Growth stage & Immature oil palm \\
Mean biomass & $10.6 \mathrm{~kg} \mathrm{ha}^{-1}$ \\
\hline Total biomass & $47.7 \mathrm{~kg}$ \\
\hline
\end{tabular}

\section{Relationship of N Status and Elevation}

Table 8 summarises the $\mathrm{N}$ recommended, $\mathrm{N}$ as-applied and biomass status on immature oil palms using the classification statistics command in ArcGIS 10.3 software shown in Figures 9, 10 and 11. A total of 5126 points were taken for determining the recommended $\mathrm{N}$ fertiliser. Based on the points, it was found that the recommended minimum and maximum values were $11.33 \mathrm{~kg} \mathrm{ha}^{-1}$ and $86.75 \mathrm{~kg}$ $\mathrm{ha}^{-1}$, respectively. Table 9 shows the recommended ranged of $\mathrm{N}$ rate starting from very low (11.3-20.0 $\mathrm{kg} \mathrm{ha}^{-1}$ ) to very high (80.1-90.0 $\left.\mathrm{kg} \mathrm{ha}^{-1}\right)$. A total of 5467 points were analysed for determining the $\mathrm{N}$ asapplied. Table 10 describes that the very low range of the $\mathrm{N}$ as-applied was $11.0-20.0 \mathrm{~kg} \mathrm{ha}^{-1}$ and while very high ranged in between $80.1-90.0 \mathrm{~kg} \mathrm{ha}^{-1}$. The biomass index was recorded at 5040 points. Table 11 shows biomass accounted to $5.0-10.0 \mathrm{~kg} \mathrm{ha}^{-1}$ was categorised as very low range, whereas very high range was in between $40.01-63.0 \mathrm{~kg} \mathrm{ha}^{-1}$.

TABLE 8. SUMMARY OF NITROGEN RECOMMENDED, NITROGEN AS-APPLIED, BIOMASS INDEX AND ELEVATION BY USING A CLASSIFICATION STATISTICS

\begin{tabular}{|c|c|c|c|c|}
\hline & $\begin{array}{l}\text { Nitrogen } \\
\text { recommended } \\
\left(\mathrm{kg} \mathrm{ha}^{-1}\right)\end{array}$ & $\begin{array}{c}\text { Nitrogen } \\
\text { as-applied } \\
\left(\mathrm{kg} \mathrm{ha}^{-1}\right)\end{array}$ & $\begin{array}{c}\text { Biomass } \\
\text { index } \\
\left(\mathrm{kg} \mathrm{ha}^{-1}\right)\end{array}$ & $\begin{array}{l}\text { Elevation } \\
\text { (m) }\end{array}$ \\
\hline Minimum & 11.33 & 11.94 & 5.04 & 20.40 \\
\hline Maximum & 86.75 & 86.75 & 62.73 & 36.20 \\
\hline Mean & 46.66 & 46.76 & 9.97 & 29.95 \\
\hline $\begin{array}{l}\text { Standard } \\
\text { deviation }\end{array}$ & 12.55 & 12.56 & 3.98 & 3.21 \\
\hline $\begin{array}{l}\text { Coefficient of } \\
\text { variance }(\%)\end{array}$ & 26.90 & 26.86 & 39.89 & 10.72 \\
\hline
\end{tabular}

TABLE 9. CLASSIFICATION OF NITROGEN RECOMMENDED

\begin{tabular}{lc}
\hline Class & Recommended rate $\left(\mathbf{k g ~ h a}^{-1}\right)$ \\
\hline Very high & $80.1-90.0$ \\
High & $60.1-80.0$ \\
Moderate & $40.1-60.0$ \\
Low & $20.1-40.0$ \\
Very low & $11.3-20.0$ \\
\hline
\end{tabular}

TABLE 10. CLASSIFICATION OF NITROGEN AS-APPLIED

\begin{tabular}{lc}
\hline Class & As-applied rate $\left(\mathbf{k g ~ h a}^{-1}\right)$ \\
\hline Very high & $80.1-90.0$ \\
High & $60.1-80.0$ \\
Moderate & $40.1-60.0$ \\
Low & $20.1-40.0$ \\
Very low & $11.9-20.0$ \\
\hline
\end{tabular}

TABLE 11. CLASSIFICATION OF BIOMASS INDEX

\begin{tabular}{lc}
\hline Class & Biomass index $\left(\mathbf{k g ~ h a}^{-1}\right)$ \\
\hline Very high & $40.01-63.0$ \\
High & $30.1-40.0$ \\
Moderate & $20.1-30.0$ \\
Low & $10.1-20.0$ \\
Very low & $5.0-10.0$ \\
\hline
\end{tabular}



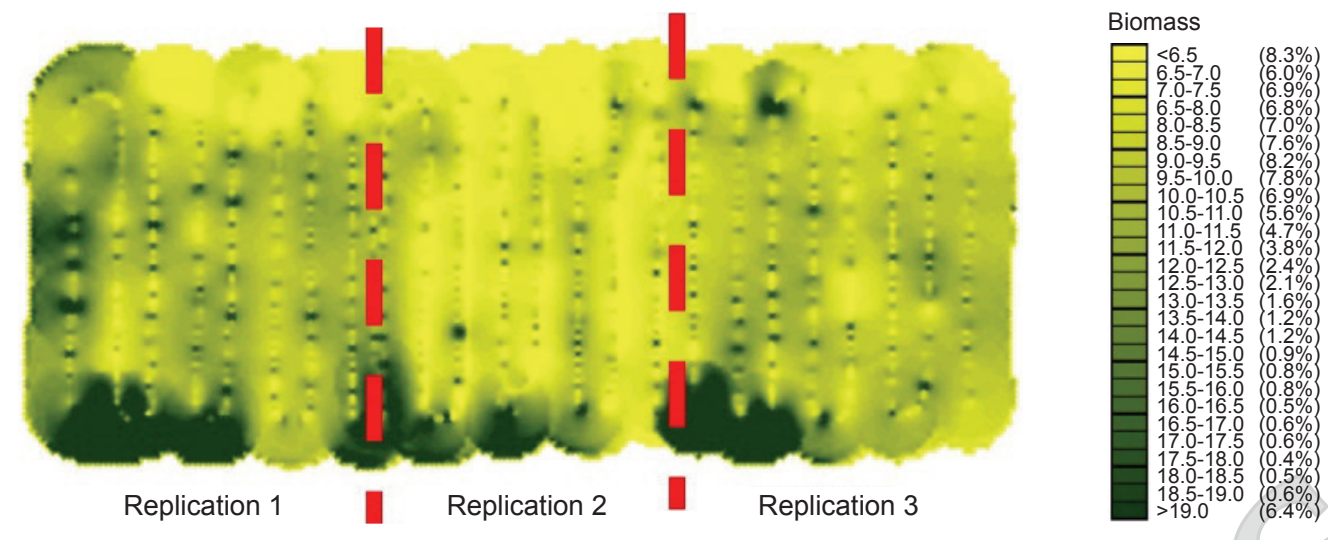

Figure 8. Biomass map.

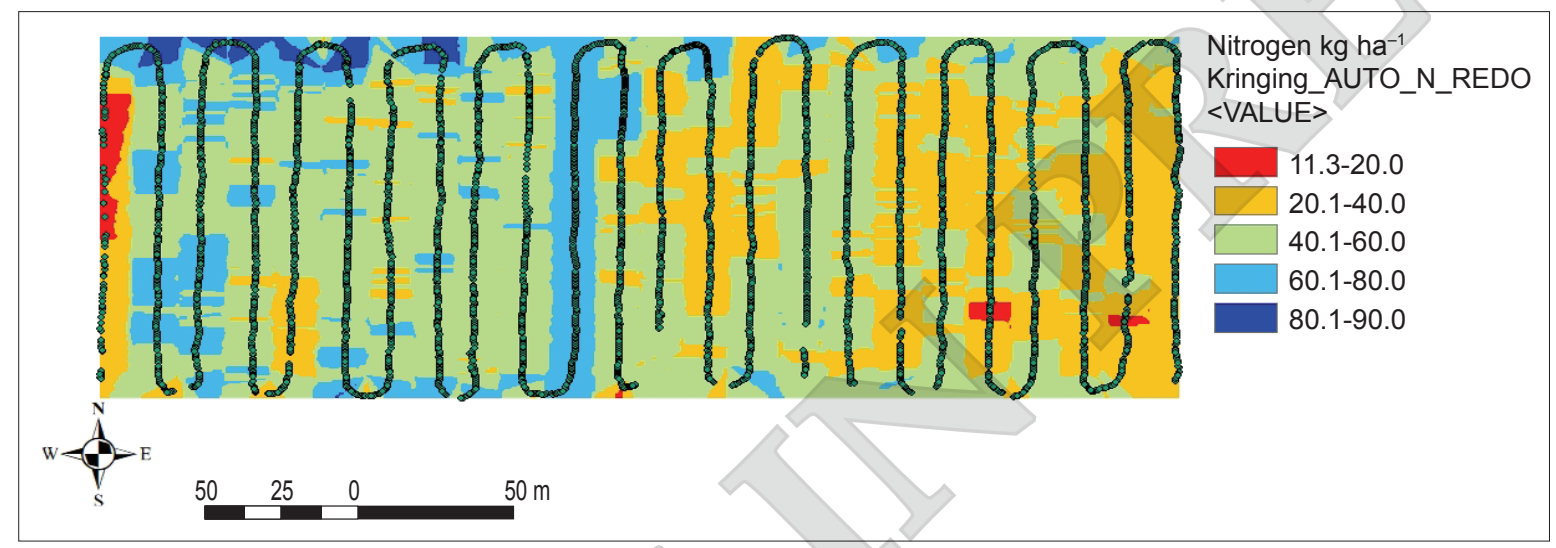

Figure 9. Spatial distribution of Nitrogen recommended on immature oil palms.

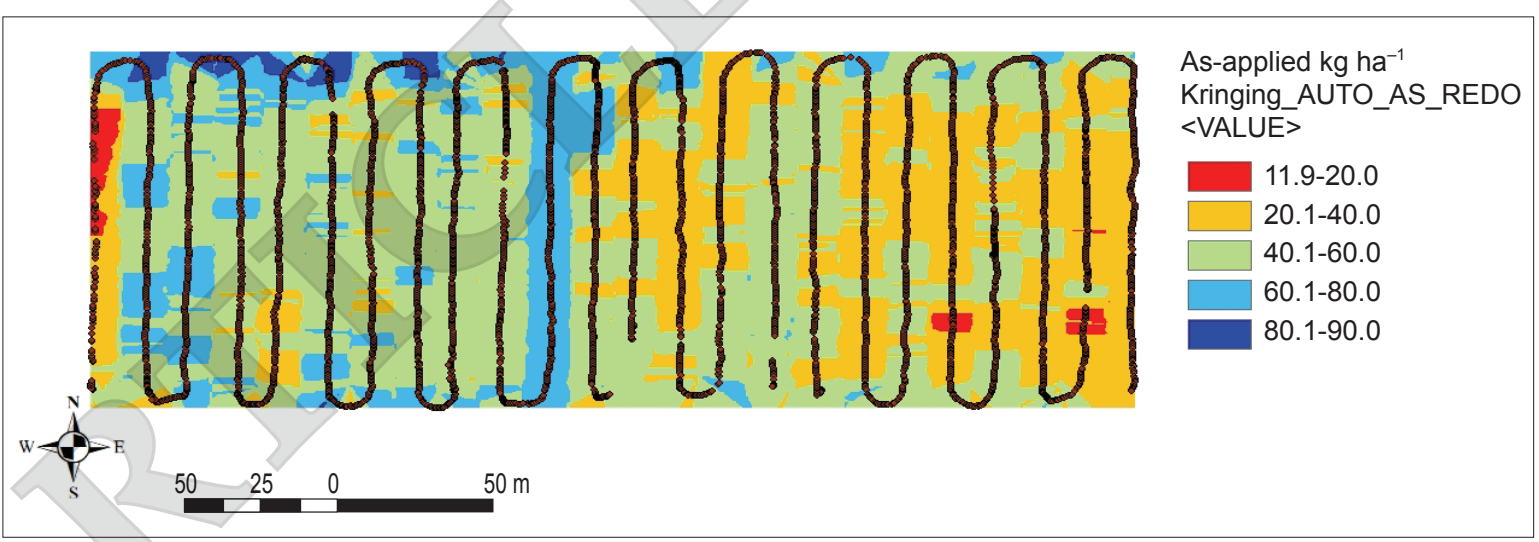

Figure 10. Spatial distribution of Nitrogen as-applied on immature oil palms.

Table 12 displays the measured elevation by GNSS attached on the tractor. The marked 3237 points gave the elevations which ranged from very low to very high. The minimum and maximum elevations in the study area were $20.40 \mathrm{~m}$ and 36.20 $\mathrm{m}$ above sea levels, respectively and the mean elevation was $29.95 \mathrm{~m}$. The coefficient of variance (CV) for $\mathrm{N}$-recommended, $\mathrm{N}$ as-applied, biomass index and the elevation were $26.90 \%, 26.86 \%, 39.89 \%$ and $10.72 \%$, respectively.
TABLE 12. CLASSIFICATION OF ELEVATION FROM GNSS ATTACHED TO THE TRACTOR

\begin{tabular}{lc}
\hline Class & Elevation range $(\mathbf{m})$ \\
\hline Very high & $33.0-36.0$ \\
High & $29.0-33.0$ \\
Moderate & $26.0-29.0$ \\
Low & $23.0-26.0$ \\
Very low & $20.0-23.0$ \\
\hline
\end{tabular}

Note: GNSS - Global Navigation Satellite System. 
A relationship between the $\mathrm{N}$ status and the terrains elevations was discovered based on the spatiality maps. Figure 12 and Table 9 indicate that the amount of $\mathrm{N}$ content ranged from very low to very high. Very low $\mathrm{N}$ content was found at rows 1, 20 and 23 (in the range of $11.3-20.0 \mathrm{~kg} \mathrm{ha}^{-1}$ ). This situation was related to the differences in elevations of these rows. As shown in Figure 12 and Table 9, the second replication and third replication; which started at the $10^{\text {th }}$ row, onwards, the highest ranges of elevation were $33-36 \mathrm{~m}$, followed by $26-29 \mathrm{~m}$ and 29-33 m above sea levels. Such areas experienced low $\mathrm{N}$ spatial distribution 20.1-40.0 $\mathrm{kg} \mathrm{ha}^{-1}$ as the areas were located at higher elevations than the others. Thus, the areas situated on higher elevation may cause higher losses of $\mathrm{N}$ fertiliser. This condition happened due to leaching, surface runoff, denitrification, volatilisation and ammonium fixation that strongly affect nutrient uptake. This is agreeing with Zhang et al. (2011), who stated that $\mathrm{N}$ mineralisation and nitrification rates decreased with increasing altitude. Previous studies in forest soils also showed the $\mathrm{N}$ mineralisation or nitrification rates were reduced by increasing altitude (Marrs et al., 1988; Kitanyanma et al., 1998; Hart and Perry, 1999). It needs a specialised treatment and better management of $\mathrm{N}$ fertiliser application. This can be done by applying the right management practice at the right place and the right time.

\section{CONCLUSION}

Early identification of $\mathrm{N}$ status is the best solution for fertilisation management practices and it can be
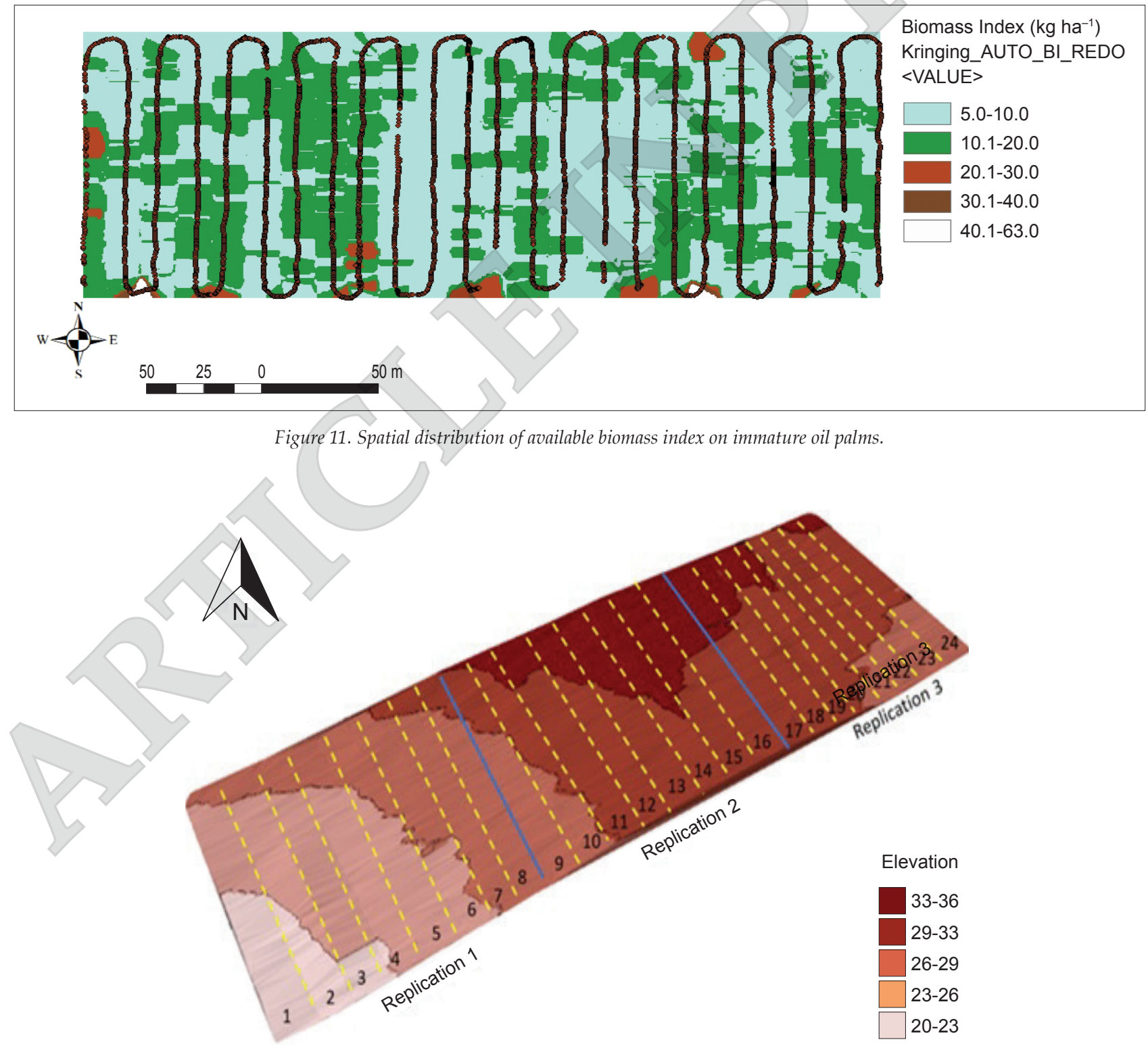

Figure 12. Spatial distribution of elevations on immature oil palms areas. 
done by using tractor-mounted N-sensor. Mapping $\mathrm{N}$ status on immature oil palm in Malaysian plantation using an autopilot tractor-mounted N-ALS had been successfully conducted in this study. The system has successfully mapped the spatial variability of $\mathrm{N}$ status on the said crop. The maps can be a reference for the oil palm plantation management to adapt the concept of VRA as one of the methods to economise the fertiliser usage in oil palm plantation. The study found that the variability of $\mathrm{N}$ ranged from low to high rates in the study area. These ranges occurred due to various levels of elevation of the area. Such diversity in elevations created a possibility of $\mathrm{N}$ leaching from the palms in the areas having higher elevations to the lower ones. Thus, application rates of $\mathrm{N}$ at certain areas (i.e. low and high elevation levels) must refer to $\mathrm{N}$ recommended map to meet the right dosage. The distribution of biomass index levels ranged from 5.0-63.00 $\mathrm{kg} \mathrm{ha}^{-1}$, which indicated that the planted crops on the study areas having a low and moderate of $\mathrm{N}$ status. A difference of $0.7 \mathrm{~kg} \mathrm{ha}^{-1}$ or $1.62 \%$ was found between mean $\mathrm{N}$ - as-applied and mean $\mathrm{N}$-recommended rates. The same phenomena also happened with the mean total $\mathrm{N}$ as-applied rate for the whole areas. The total $\mathrm{N}$-as applied rate for the whole areas was $3.1 \mathrm{~kg}(1.60 \%)$ lower than the recommended one. The findings also concluded that this mapping system can assist plantations in saving $0.7 \mathrm{~kg} \mathrm{ha}^{-1} \mathrm{~N}$ fertiliser.

Generally, the study also proved that this technology is suitable to be used to monitor $\mathrm{N}$ status on a wide range of crops, including tree crops such as oil palm. However, its application on oil palm is only suitable during immature stage. Other than that, tractor with autopilot-automated steering can be an alternative prime mover to operate the sensor in the oil palm plantation terrain. It was observed that with hands-free driving, the autopilot tractor is able to give various assistances to the operator, especially operator comfort during driving. It is recommended to carry out further study on mapping the $\mathrm{N}$ status on immature oil palm with autopilot tractor-mounted N-sensor while moving on various slopes in oil palm plantations. In addition, evaluation of the sensor operated by various driving systems of tractor is also advocated.

\section{ACKNOWLEDGEMENT}

The authors are very grateful to the Sime Darby Plantation Berhad, especially to the management of Sime Darby Plantation at Kempas Estate in Jasin, Melaka, Malaysia for its continuous support as well as giving the access toward knowledge either directly or indirectly throughout the research period.

\section{REFERENCES}

Amirruddin, A and Diyana, A (2017). Nitrogen effects on growth and spectral characteristics of immature and mature oil palms. Asian J. Plant Sci., 16(4): 200-210.

Bechar, A and Vigneault, C (2016). Agricultural robots for field operations: Concepts and components. Biosyst. Eng., 149: 94-111.

Bechar, A and Vigneault, C (2017). Agricultural robots for field operations. Part 2: Operations and systems. Biosyst. Eng., 153: 110-128.

Bello, R S (2012). Agricultural Machinery and Mechanization. CreateSpace 7290 B. Inv. Drive Charl US. https: / / www.createspace.com/3497673, accessed on 15 January 2020.

Bergtold, J S; Raper, J S and Schwab, E B (2013). The economic benefit of improving the proximity of tillage and planting operations in cotton production with automatic steering. Appl. Engin. in Agric., 25(2): 133-143.

Bragagnolo, J; Amado, T J C; Nicoloso, R S; Jasper, J; Kunz, J and Teixeira, T G (2013). Optical crop sensor for variable-rate nitrogen fertilization in corn: I Plant nutrition and dry matter production. R. Bras. Ci. Solo, 37: 1288-1298.

Elsayed, S; Rischbeck, P and Schmidhalter, U (2015). Comparing the performance of active and passive reflectance sensors to assess the normalized relative canopy temperature and grain yield of droughtstressed barley cultivars. Field Crops Res, 177: 148-160.

FAO (2014). A Regional Strategy for Sustainable Agricultural Mechanization: Sustainable Mechanization Across Agri-Food Chains in Asia and the Pacific Region. RAP Publication 2014/24. Food and Agriculture Organization (FAO). p. 74-78.

Gasim, M B; Ismail, B S; Mir, S I; Rahim, S A and Toriman, M E (2011). The physico-chemical properties of four soil series in Tasik Chini, Pahang, Malaysia. Asian J. Earth Sci., 4(2): 75-84.

Goh, K J and Harter, D (2003). General Oil Palm Nutrition: Oil Palm: Management for Large and Sustainable Yields. Potash and Phosphate Institute, Singapore. p. 191-230.

Gianquinto, G; Munoz, G; Pardossi, G; Ramazzoti, G and Savvas, D (2013). Good Agricultural Practices for Greenhouse Vegetable Crops: Principles for Mediterranean Climate Areas. Food and Agriculture Organization (FAO). p. 205-262. 
Hart, S C and Perry, D A (1999). Transferring soils from high-to low elevation forests increases nitrogen cycling rates: Climate change implications. Global Change Biol, 5: 23-32.

Husin, M E (2017). Rapid nutrition mapping system for paddy field in Malaysia. Proc. of the Seminar on Data Driven Agriculture. http://itfnet.org/ Download/DataDrivenAgriculture/5.pdf, accessed on 20 June 2020.

Jifon, J L and Whaley, E (2005). Growth environment and leaf anatomy affect nondestructive estimates of chlorophyll and nitrogen in Citrus sp. leaves. J. Amer. Soc. for Hort. Sci., 130(2): 152-158.

Kitanyanma, K; Aiba, S I; Lee, N M and Ohsawa, M (1998). Soil nitrogen mineralization rates of rainforests in a matrix of elevations and geological substrates on Mount Kinabalu, Borneo. Ecol. Res., 13: 301-312.

Kushairi, A; Singh, R and Ong-Abdullah, M (2017). The oil palm industry in Malaysia: Thriving with transformative technologies. J. Oil Palm Res. Vol. 29(4): 431-439.

Lipinski, A J; Markowski, P; Seweryn, L and Pyra, P (2016). Precision of tractor operations with soil cultivation implements using manual and automatic steering modes. Biosyst Eng, 145: 22-28.

Lewis, K; Rumpang, E; Kho, L K; McCalmont, J; Teh, Y A; Gallego-Sala, A and Hill, T C (2020). An assessment of oil palm plantation aboveground biomass stocks on tropical peat using destructive and non-destructive methods. Sci. Reports, 10: 2230.

Marrs, R H; Proctor, J; Heaney, A and Mountford, M D (1988). Changes in soil nitrogen-mineralization and nitrification along an altitudinal transect in tropical rain forest in Costa Rica. J. Ecol., 76: 466-482.

Molin, J P and Port, G (2010). Using an active crop sensor to detect variability of nitrogen supply on sugar cane fields. The LAP. https:// www.agriculturadeprecisao.org.br/wp-content / uploads/2020/01/cgr_2010-03.pdf, accessed on 22 September 2020.

Muñoz-Huerta, R F; Guevara-Gonzalez, R G; Contreras-Medina, L M; Torres-Pacheco, I; PradoOlivarez, J and Ocampo-Velazquez, R V (2013). A review of methods for sensing the nitrogen status in plants: Advantages, disadvantages and recent advances. Sensors, 13(8): 10823-10843.

Mulla, D J (2013). Twenty-five years of remote sensing in precision agriculture key advances and remaining knowledge gaps. Biosyst. Engin., 114(4): 358-371.

$\mathrm{Ng}$, S K (1979). Greater productivity of the oil palm (Elaies guineensis Jacq.) with efficient fertilizer practices. Proc. of the International Potash and Phosphate Institute. p. 357-376.

$\mathrm{Ng}$, S K (1977). Review of oil palm nutrition and manuring. Scope for greater economy in fertilizer usage. Oleaginueux, 32: 197-209.

Pebrian, D E; Yahya, A and Siang, T C (2014) Workers' workload and productivity in oil palm cultivation in Malaysia. J. Agric. Saf. and Hlty, 20(4): 235-254.

Poorter, H; Jagodzinski, A M; Ruiz-Peinado, R; Kuyah, S; Luo, Y; Oleksyn, J; Usoltsev, V A; Buckley, T N; Reich, P B and Sack, L (2015). How does biomass distribution change with size and differ among species? An analysis for 1200 plant species from five continents. New Phytol., 208(3): 736-749.

Samborski, S; Marek, S; Tremblay, N and Fallon, E (2009). Strategies to make use of plant sensorsbased diagnostic information for nitrogen recommendations. Agron. J., 101(4): 800-816.

Sharma, A; Singh, M and Jasper, J (2012). Investigation on tractor mounted n-sensor for wheat crop in India. Proc. of Agro-Informatics and Precision Agriculture 2012. p. 137-141.

Singh, M; Kumar, R; Sharma, A; Singh, B and Thind, S K (2015). Calibration and algorithm development for estimation of Nitrogen in wheat crop using tractor mounted N-sensor. The Sci. World J., 2015(163968): 1-12.

Trimble (2014a). Trimble ${ }^{\circledR}$ EZ-Pilot $^{\circledR}$ Steering System: International Harvester 86 and 88 Series Tractors. Version 5.0. Revision A. Trimble Agriculture Division. Westminster. Colorado., USA. p. 20-31.

Trimble (2014b). Trimble ${ }^{\circledR}$ TMX-2050 TM Display. Version 1.075. Revision D. Trimble Navigation Limited. Sunnyvale. California., USA. p. 13-16.

Tremblay, N; Wang, Z; Ma, B; Belec, C and Vigneault, $P$ (2008). A comparison of crop data measured by two commercial sensors for variable-rate nitrogen application. Precision Agric., 10(2): 145-161.

Yang, G; Liu, J; Zhao, C; Li, Z; Huang, Y; Yu, H; Xu, B; Yang, X; Zhu, D; Zhang, X; Zhang, R; Feng, H; Zhao, X; Li, Z; Li, H and Yang, H (2017). Unmanned aerial vehicle remote sensing for field-based crop 
phenotyping: Current status and perspectives. Front. Plant Sci., 8 (1111): 1-26.

Yara International (2015). Introducing the Yara N-Sensor. Complete Solution to Precision Farming. www.yara.co.uk., accessed on 15 January 2020.
Zhang, S; Chen, D; Sun, D; Wang, X; Smith, J L and Du, G (2011). Impacts of altitude and position on the rates of soil nitrogen mineralization and nitrification in alpine meadows on the eastern Qinghai-Tibetan Plateau, China. Biol. Fertil. Soils, 48: 393-400. 